\title{
Mental Bases of National Security of the Baikal Subregion in the Euroasian Space
}

\author{
Inna V. Antokhonova* \\ East Siberia State University \\ of Technology and Management \\ 40V Klyuchevskaya Str., Ulan-Ude, 670013, Russia
}

Received 30.05.2016, received in revised form 26.07.2016, accepted 15.09.2016

The escalated competition and complicated geopolitical processes bring to the fore the issues of the national security of Russia and its border territories. The aspects of the economic relations development in eastern regions which directly adjoin the Asian states in the conditions of the international sanctions, falling of oil price and orientation to the east are ambiguous. The objective of this research is the development of conceptual bases of the national security in the Baikal subregion taking into account changes of human mentality in the conditions of market relations. The methods are based on Toynbee civilization approach and the need of preservation and development of the local civilization. The article presents results of households' selective inspection in the border municipal districts of Buryatia on the basis of the universal questionnaire within the scientific project of the Russian Foundation for Basic Research. The study determines economic interests and criteria of preservation of the main component of territories' capacity: human resources.

Keywords: mentality, security, local civilization, Baikal subregion.

The research is carried out with the financial support of the Russian Foundation for Basic Research and the Government of the Republic of Buryatia (project No. 15-46-04388).

DOI: 10.17516/1997-1370-2016-9-11-2756-2764.

Research area: economics.

\section{Introduction}

New challenges of global economy and formation of the multipolar world define the problems of preserving the sustainable development of national economies. Border development of regions of Russia in the Euroasian space is especially relevant. The assessment of system risks is necessary for national security from the standpoint of the stability of regional social and economic systems. Sustainable civilized development includes issues of national, economic, social, cultural and ecological security. In open economy there is a paradigm shift of mental behaviour, the eastern type of mentality is leaving metropolises and the regional centers and is replaced by the western style of behaviour.

(c) Siberian Federal University. All rights reserved

* Corresponding author E-mail address: iv.antokhonova@gmail.com 
In such conditions the worthy answer to the challenges of global economy is possible from the consolidated socially related society with effective and representative elite which have former traditions in mentality and the developing system of values.

There is an objective need for scientific justification of the strategy of the Russian regions' development till 2030 in the conditions of the changing mentality of the population in the Euroasian space.

The space of Russia and its regions is Eurasia adjoining the Roman Christian civilization from the west, the population of Russia shares mainly Byzantine orthodox spiritual culture with presence of Islam and Buddhism in national historical territories. It creates a variety and richness of traditions, cultures, stories and at the same time in the conditions of economic crisis can generate conflict situations. Russia is open for international communication. In this regard, attempts to search for the Russian national identity occur in severe conditions of the competition between the eastern and the western mentality with different systems of values. The development of the human resource potential of the territories is influenced by external and internal calls, demands the estimate of economic interests of all institutional units - households, business and the state.

The development of multinational and multireligious Russia in the global world lies in the area of humanitarian problems of the multipolar changing world. The dynamic development in the $21^{\text {st }}$ century significantly differs from the bipolar world of the last century when the USSR resisted to the USA in scientific and military spheres, being the multinational power. Disintegration of the system, search of new partners, the competition for human and natural resources generate new internal and external challenges for the national security of Russian regions.

\section{Research methods}

There are a lot of approaches to the study of the national economic security. The law of the Russian Federation "About safety" defines the economic security of Russia as the protection of the vital interests of all country residents, the Russian society in general and the states in the economic sphere from internal and external threats.

Internal threats to preservation of the national economy integrity arise at violation of balance in processes of involvement of resources in economic circulation. Resource-based character of the economy creates dependence on the demand, world prices for resources and the rate of national currency. Orientation on cheap labour constrains the development of technologies and replacement of human labour with materialized one.

Kondratyev's theory of long waves or business cycles had the defining value for the development of the society. Peculiarity of the cycles' evolution includes the substitution of one basic innovations by other ones which after their own life cycle, give way to the new ones. The personality, the individual in this process plays different roles from the idea man and the implementor to the end user of new goods and services. The previous waves provided new technologies and power sources, information and communication technologies allowing to easily overcome spaces and expand personal space, to develop communications, to release time for creativity and development. However, the increasing production of more and more consumer goods was a test for the consumer and has changed the need for the development of the society, specific communities and individuals. Since the classical works by M. Weber, J. Dewey, U. Thomas, F. Znanetsky, P. Sorokin and T. Parsons, the research of values has continued in the modern western science in the works of P. Blau, S. Schwartz, M. Rokeach, R. Budon, 
R. Inglehart, C. Kluckhohn, J. Habermas, N. Elias, A. Etzioni, H. Joas, H. Zetterberg and M. Kohn. In the Soviet and Post-Soviet sociology A. Zdravomyslov, V. Yadov, T. Lyubimova, I. Surina, V. Spiridonova, V. Bakirov, A. Ruchka, E. Podolskaya, I. Popova and many other scientists addressed the problem of values. The American social psychologist Milton Rokeach has developed the theoretical system of values with two main types of values: terminal (values- purposes) and instrumental (values-means), each of which has been presented by 18 specific subtypes. Such values as completeness of life, wisdom, health, love, finanical well-being belong to the first type. The second type of values-means is presented by various personal traits: accuracy, nice behaviour, cheerfulness, independence, etc.

Rokeach's developments were continued by the Israeli social psychologist Shalom Schwartz who has managed to practically implement all previous achievements in the field of the sociological and general theory of values.

Concepts of the post-industrial information society consider information as a backbone factor.

The academician V. L. Makarov states the following thesis: the mission of Russia is to preserve the ethnic, ideological and religious variety in the world. The society develops in the conditions of new challenges with increasing personal problems, conditions when the market offers the models of mainly consumer behaviour.

According to the corresponding member of the Russian Academy of Sciences G. B. Kleiner, the modern Russian society is divided, fragmentary, broken up into the low-connected fragments, i.e. losing integrity as a system. In the society with broken links from the point of view of the system approach new integrative properties would not appear, therefore it loses the development potential. Such society loses the social capital. The humanitarian geography
(1984, D. V. Nikolayenko), the interdisciplinary scientific approach studying various ways of representation and interpretation of terrestrial spaces in the human activity including mental (mental) activity, deserves special attention. In the late nineties the term was appropriated by the school of Russian geographer and culture specialist D.N. Zamyatin to unite the independent scientific approaches having many common features in research methods into a unified scientific field.

Statistical aspects of the quality of life, social problems, shadow economy have gained development in the studies of S.A. Aivazyan, I.I. Eliseeva, institutional issues of interaction of the state, business and households have found reflection in the works of R.M. Nureev and others. V.S. Zagashvili's approach to the research is based on the assessment of national interests and interests of individuals and social groups (Zagashvili, 1995).

\section{Problem Statement}

Russia is multinational and diverse in all natural and geographical meanings. Therefore, the processes with the economic nature predominate there: promising education, qualitative health care, search of the developed labour market, the comfortable place of residence and education for children, socially protected old age, etc. Humanitarian problems in the conditions of instability and post-crisis recession go to the background. The national, ethnic and historical roots and traditions forming the mentality are sometimes replaced with the market substitutes imitating well-being symbols in the sphere of leisure, entertainment, show business and tourism. Hedonistic tendencies disseminate especially among young people via social networks and modern communications. The problem consists in the need for identification of the processes stopping and limiting humanitarian development 
of the society and the search of approaches, strategy and ways of movement to the sustainable, balanced and harmonious development of the society.

The studies described above belong to the national economy. The regional economy due to smaller scales and low competitiveness is exposed to risk of loss of human resources, both in the form of residents and owners of small business. The development of the problem of quality and economic security of life at the regional level from the positions of the interdisciplinary system approach is not sufficient. With the loss of the human resources which perform the most significantrole, the potential of the eastern subjects is exposed to the bigger risk of loss of integrity and potential. From the positions of humanitarian geography it is necessary to consider economic spaces, mental models and cognitive processes in unity.

The approach to the object as to a complicated system is based on the principles of systemacity, balance, emergence and multiplicativity.

Steady integrity depends on balance of the resources involved in economic circulation. The system has the features of emergence of the integrative properties not inherent in separate components. The development potential capable to lead to multiplicative effects in the course of consecutive involvement of necessary resources and creation of the market environment is formed.

It is necessary to reveal the general mental bases and to identify the local territory actually representing the object of research which is a part (an element, a subsystem) of the object of the higher level. The Baikal subregion uniting three subjects of Eastern Siberia, the Irkutsk region, the Republic of Buryatia and Zabaykalsky Krai with population of 4,489 million people and with the total area of 1558 thousands $\mathrm{km}^{2}$, is considered as such object.
The main tasks in solving the problem of preserving sustainability and national security are:

- justification of the civilization interdisciplinary approach from the position of the priority of human resources;

- justification of the principles and approaches to study the national security by means of research of the subregion as a part of the national economy;

- identification of the potential of the human resources localized at the territory of the object in close proximity to the states of Eurasia.

Scientific novelty of the research consists in the following:

- application of the civilization interdisciplinary approach to the development of methods to ensure national security of the territories and regions of Russia adjoining the states of Eurasia;

- the choice of the target audience of the survey taking into account the purposes and strategy of patriotic, multicultural and national development of regions in Russia;

- the main focus of the research is on the young target audience and formation of their system of values, while the dialogue with them is mostly carried on by the people from the education and scientific fields;

- assessment of the potential of social clusters in the society of the Baikal subregion by ethnic, economic, social, religious and other features in terms of their adequacy in the Euroasian space;

- identification of the reasons of domination and possible change of consumer behaviour to the evolutionary one;

- development of socialization in the society including the use of network technologies which is essential for the regions of Russia with low population density (2.7 people/sq. $\mathrm{km}$ in Buryatia and 8 people/sq.km. in Russia); 
- search for mechanisms to develop a interrelated recreational space preserving human resources in the territory;

\section{Methods}

The research is based on the civilization approach of Toynbee who considers a local civilization as the main unit of history which collides with other civilizations during its development. The civilization with the potential to better cope with challenges objectively receives an impulse for development. The main competition is for human and natural resources having a natural unique origin, and in this sense having wealth, variety and irreproducibility.

The methodology of the civilization approach sets the task of specifying the modern concept of space, borders, kernel, reproduction and functions of the civilization. The possibility of certain territories development with the carriers of civilization assumes the transformation character unlike the adaptation one, which is typical for a weak local civilization.

The western civilization is based on private property and possibility of its preservation and institutional transfer. The state does not interfere with the private life of law-abiding citizens. The mentality is characterized by the emphasized respect for the law, private business, steady relation to material benefits of life defining its quality that had been developed through the entire period of the market economy. The oriental civilization is characterized by stability unlike dynamic change in the West, preservation and transfer of traditions, states the impossibility of possessing property due to the material recession of a person and parting with the saved-up wealth and attachments on the earth where all material will pass off and does not have the superior significance.

In the course of globalization, more and more close interrelations between open national economies, the increased mobility of the population there are integration processes and interpenetration of traditions and cultures. These processes affect also mental bases of the society and the research of spatial aspects of interpenetration of civilizations acquires special relevance and interest for science, politics, society and business.

The research is based on the heuristic and formalized methods which supplement each other depending on information security, entropy regularities, possibility to use various measuring scales. The object is studied using the methods of descriptive statistics by structure and in time, with identification and opening of the problems of mental character which do not lie on the surface, establishment of cause and effect dependences on the basis of statistical methodology and tools including exploratory data analysis, factor analysis, cluster analysis, fuzzy logic and neural networks.

\section{Discussion}

In the last decade political and economic transformations in the territory of the Euroasian space has become quite active. Russia comes to the forefront in the international organizations and the former Soviet Union: BRICS (Brazil, Russia, India, China, Republic of South Africa), SCO (China, Russia, Kazakhstan, Tajikistan, Kyrgyzstan), EEU (Armenia, Belarus, Kazakhstan, Kyrgyzstan, Russia). In terms of geopolitics, the issue regarding the possible multipolar world and objective strengthening of economic influence of the Asian countries in the Euroasian space is being discussed.

The knowledge of the studies and empirical experience allow to mark out the following essential features of the mental space in the world:

various archetypes of the elite representing the country in the global world and defining mental samples; 
change of the eastern mentality with the western model in metropolises, large and medium-size cities;

convergence of behaviour models by means of rapid development of mobile services and social networks;

strengthening of divergence on the periphery in comparison with city agglomerations;

increase of the generation gap at certain types of the age structure;

growth of opportunities to develop modern mental and behavioural model basing on personal experience due to the increasing mobility of the population.

Social and economic development of Mongolia which is not included in the provided list of the organizations which age structure of the population sharply differs from other countries of the Euroasian space is of a great interest (Table 1). This country has preserved national eastern mentality and actively develops private business, one third of the population consists of children focused on integration and learning oriental and European languages. The country has latent opportunities of spatial potential preserving historical proportions of the number of population/livestock/territory.
Development of bases of national security on the example of the Baikal subregion assumes the assessment of integrity of the object (Table 2). The conceptual scheme of research of the interregional integration consists of five analytical blocks (Kolodina, 2004):

a) analysis of interregional economic streams and degree of integration of the regions in national and world economy;

b) analysis of efficiency of integration projects with participation of economic entities of two and more regions;

c) analysis of the level of the interregional integration influence on the economic situation in the regions and the national economy in general;

d) identification and analysis of the interregional economic systems (platforms);

e) analysis of the barriers of the interregional economic integration and reasons of their emergence.

Among the given blocks the last one as the competition in the local markets is essential, the existence of a natural rent on the electric power gives an advantage to the enterprises of the Irkutsk region. Regions are rather close in terms of the national structure of the population, it allows to speak about the general mental bases

Table 1. Age Structure of the Population of Russia and Countries of Asia (Mikhail Pavlov, 2007 — 2014, http:// www.mir-geo.ru/)

\begin{tabular}{|c|c|c|c|c|c|}
\hline \multirow[b]{2}{*}{ Country } & \multicolumn{3}{|c|}{ Country population by age, $\%$} & \multirow{2}{*}{$\begin{array}{l}\text { Population } \\
\text { density, } \\
\text { person } / \mathrm{km}^{2}\end{array}$} & \multirow{2}{*}{$\begin{array}{c}\text { Average } \\
\text { duration } \\
\text { of life, years }\end{array}$} \\
\hline & Until 14 & $15-64$ & $\begin{array}{l}\text { Older than } 65 \\
\text { years and more }\end{array}$ & & \\
\hline Russia & 17.41 & 69.78 & 12.81 & 8.39 & 69.8 \\
\hline Kazakhstan & 26.73 & 66.03 & 7.24 & 5.96 & 67.35 \\
\hline Belarus & 17.93 & 68.21 & 13.86 & 45.61 & 70.2 \\
\hline Mongolia & 32.99 & 63.13 & 3.88 & 1.77 & 67.05 \\
\hline China & 25.01 & 67.88 & 7.11 & 139.57 & 72.95 \\
\hline South Korea & 21.59 & 71.14 & 7.27 & 501.37 & 75.36 \\
\hline Japan & 14.64 & 67.83 & 17.53 & 337.16 & 82.15 \\
\hline North Korea & 25.52 & 67.63 & 6.85 & 199.03 & 72.0 \\
\hline
\end{tabular}


Table 2. The Main Indicators of the Baikal Region in $2012^{1}$

\begin{tabular}{|c|c|c|c|c|c|c|}
\hline $\begin{array}{c}\text { Territorial } \\
\text { subjects of } \\
\text { the Russian } \\
\text { Federation }\end{array}$ & $\begin{array}{c}\text { Population, } \\
\text { thousands of } \\
\text { persons. } \\
\text { as of } 1 / 1 / 2013\end{array}$ & $\begin{array}{c}\text { Area, } \\
\text { thousands } \\
\text { sq.km }{ }^{2}\end{array}$ & $\begin{array}{c}\text { GRP, } \\
\text { millions } \\
\text { RUB }\end{array}$ & $\begin{array}{c}\text { Share } \\
\text { in GDP of } \\
\text { the Russian } \\
\text { Federation }\end{array}$ & $\begin{array}{c}\text { Investments } \\
\text { Into the fixed } \\
\text { capital, } \\
\text { millions RUB. }\end{array}$ & $\begin{array}{c}\text { Average monetary } \\
\text { income per capita of the } \\
\text { population } \\
\text { per month, RUB. }\end{array}$ \\
\hline $\begin{array}{c}\text { Zabaikalsky } \\
\text { krai }\end{array}$ & $1,095.2$ & 431.9 & $208,257.7$ & 0.5 & 58,129 & $17,335.6$ \\
\hline Irkutsk region & $2,422.0$ & 774.8 & $627,856.2$ & 1.4 & 156,470 & $17,720.3$ \\
\hline $\begin{array}{c}\text { Republic of } \\
\text { Buryatia }\end{array}$ & 971.8 & 351.3 & $154,677.7$ & 0.3 & 41,039 & $17,119.0$ \\
\hline Total & 4,489 & 1,558 & $990,791.6$ & - & 255,638 & - \\
\hline
\end{tabular}

of the population. At the level of economic development the subjects hold an average position in the Siberian Federal District.

At the first stage of implementation of the project, the Russian Federal Property Fund conducted field research in the municipal districts of Buryatia which were among remote, border and having recreational potential: Barguzin District, Zakamensky District, Kyakhtinsky District, Okinsky District and Tunkinsky District.

The universal questionnaire including 22 questions was developed for the purpose of data collection covering the following areas:

- assessment of the potential of the specific territory;

- assessment of the potential of transformation of households' resources;

- assessment of motivation for settling in the territory;

- demand for state support of business;

- values and trust in the society.

For processing of the results of the survey the database was developed. As an example of differentiation of the territories in terms of motivation for settling in the territory let us demonstrate the predominating answers by districts to the question "Which conditions will allow you to stay or come back?":
Quality of training at schools (Okinsky District)

Development of infrastructure (Kyakhtinsky District)

Housing (Barguzin District)

Quality of medical services (Zakamensky District)

Granting of land (Tunkinsky District).

Economic and social conditions are in the centre of attention which proves that these problems are acute and require state regulation.

\section{Conclusion}

The survey results are significant for the development of recommendations, which forms the Strategy of Buryatia Development till 2030. The research results can be used for the assessment of the quality of life, provided services in the fields of education, culture, healthcare and social protection.

The society in the conditions of recession works out the adaptation strategy (without social protests), involvement of human resources in the uniform cognitive space is necessary for discussion of prospects of development in the Euroasian space. The most difficult task is preservation of competitive human resources for the purpose of formation of elite, preservation of geographical borders and elimination of mental ones.

\footnotetext{
Regiony Rossii. Sotsio-ekonomicheskie indeksy [Regions of Russia. Socio-economic Indexes] (2013). P32 Statistical Col-
} lection, Rosstat, Moscow, 990 p. 


\title{
References
}

Ivanter, V. V., Kozhemyako, O.N. \& Kuvalin, D.B. (2013). Dolgosrochnoe sotsial'noekonomicheskoe razvitie Dal'nego Vostoka i Zabaikal'ia: osnovnye problem i zadachi [Long-term social and economic development of the Far East and Transbaikalia: main problems and tasks], In Studies on Russian Economic Development, 4, 3-14.

Kalenova, S.A. (2013). Potentsial Respubliki Kazakhstan v predstoiashchie desiatiletiia. Ekonomiko-statisticheskie issledovaniia potentsiala territorii $v$ sovremennom informatsionnom obshchestve [Capacity of the Republic of Kazakhstan in the forthcoming decades. Economical and statistical research of the capacity of territories in modern information society]. Sbornik materialov II mezhdunarodnoi nauchno-prakticheskoi konferntsii [Collection of materials of the II international scientific and practical conference]. Ulan-Ude, VSGUTU Publishing House, 121-124.

Kolodina, E.A.(2004). Teoriia i metodologiia regulirovaniia mezhregional'noi ekonomicheskoi integratsii [Theory and methodology of regulation of interregional economic integration]. Irkutsk, BGUEP Publishing House, 271p.

Krugman, P. (1991). Increasing Returns and Economic Geography, In Journal of Political Economy, 3 (99), 483-499.

Kuz'mino, Ia.I. (2012). Rutiny i mental'nye modeli [Routines and mental models]. Copyright 2012 (C) Elitarium (www.elitarium.ru).

Lee Kuan Yew, (2000). From Third World to First: The Singapore Story - 1965-2000. Harper, $752 \mathrm{p}$.

Zagashvili, V.S. (1995). Natsional'naia ekonomicheskaia bezopasnost' [National economic security], In Obshchestvennye nauki i sovremennost' [Social sciences and Modernity], 2, 15-24.

\section{Ментальные основы}

\section{национальной безопасности}

Байкальского субрегиона

в евразийском пространстве

\author{
И.В. Антохонова \\ Восточно-Сибирский государственный университет \\ технологий и управления \\ Россия, 670013, Улан-Удэ, ул. Ключевская, 40в
}

В условиях обостривщейся конкуренции и сложных геополитических процессов актуальными становятся вопросы национальной безопасности России и ее приграничных территорий. Неоднозначными являются аспекты формирования экономических отношений в восточных регионах, непосредственно граничащих с азиатскими государствами, в условиях международных санкций, падения ценны на нефть и ориентациии на Восток. Целью исследования является разработка концептуальных основ начиональной безопасности в Байкальском субрегионе с учетом изменений менталитета населения в условиях рыночных отношений. Методология базируется на циивилизационном подходе Тойнби и необходимости сохранения и развития ло- 
кальной цчивилизации. В статье использованы результаты выборочного обследования домохозяйств приграничных муниципальных районов Бурятии на основе универсальной анкетьл в рамках научного проекта РФФИ1. Выявлены экономические интересы и критерии сохранения главной составляющей потенщиала территорий - человеческих ресурсов.

Ключевые слова: ментальность, безопасность, локальная циивилизация, Байкальский субреги$\mathrm{OH}$.

Исследование проводится при финансовой поддержке Российского фонда фундаментальных исследований и Правительства Республики Бурятия (проект № 15-46-04388).

Научная специальность: 08.00.00 - экономические науки. 